\title{
PENGARUH PEMBERDAYAAN PEGAWAI, DUKUNGAN ORGANISASI DAN KOMPENSASI TERHADAP KOMITMEN ORGANISASIONAL
}

\author{
Kadek Desniari ${ }^{1}$ \\ A.A Sagung Kartika Dewi ${ }^{2}$ \\ ${ }^{1,2}$ Fakultas Ekonomi dan Bisnis Universitas Udayana, Bali, Indonesia \\ email:kadekdesniari@gmail.com
}

\begin{abstract}
ABSTRAK
Tujuan penelitian ini adalah untuk mengetahui pengaruh pemberdayaan pegawai, dukungan organisasi dan kompensasi terhadap komitmen organisasional. Penelitian ini dilakukan di Kementerian Pekerjaan Umum dan Perumahan Rakyat Balai Wilayah Sungai Bali-Penida. Jumlah sampel yang diambil sebanyak 65 orang pegawai dengan status sebagai pegawai kontrak/non PNS. Teknik analisis yang digunakan adalah regresi linier berganda. Berdasarkan hasil analisis ditemukan bahwa pemberdayaan pegawai, dukungan organisasi dan kompensasi secara simultan berpengaruh positif dan signifikan terhadap komitmen organisasional. Pemberdayaan pegawai secara parsial berpengaruh signifikan terhadap komitmen organisasional. Dukungan organisasi secara parsial berpengaruh terhadap komitmen organisasional. Kompensasi juga secara parsial berpengaruh signifikan terhadap komitmen organisasional.
\end{abstract}

Kata kunci: pemberdayaan pegawai, dukungan organisasi, kompensasi, komitmen organisasional.

\begin{abstract}
The purpose of this study was to determine the effect of employee empowerment, organizational support and compensation on organizational commitment. This research was conducted at Kementerian Pekerjaan Umum dan Perumahan Rakyat Balai Wilayah Sungai Bali-Penida. The number of samples taken was 65 employees with contract / non civil servant status. The analysis technique used is multiple linear regression. Based on the results of the analysis it was found that employee empowerment, organizational support and compensation simultaneously had a positive and significant effect on organizational commitment. Partial employee empowerment has a significant effect on organizational commitment. Organizational support partially influences organizational commitment. Compensation also has a partially significant effect on organizational commitment.

Keywords: employee empowerment, organizational support, compensation, organizational commitment.
\end{abstract}




\section{PENDAHULUAN}

Pengaruh perkembangan globalisasi membuat tekanan persaingan bisnis semakin ketat, banyak perusahaan di Indonesia mewajibkan pegawainya untuk meningkatkan keunggulannya disegala bidang dalam pencapaian kinerja yang maksimal. Perkembangan globalisasi yang didukung oleh perkembangan teknologi tentu membuat perusahaan untuk lebih efektif dan efisien dalam pengelolaan sumber daya manusia yang berkompeten agar dapat bertahan dalam persaingan yang semakin ketat. Perusahaan dalam mengelola sumber daya manusia yang baik, setiap pimpinan perusahaan serta bagian yang mengenai sumber daya manusia harus mengerti masalah mengenai manajemen dengan baik (Widodo, 2015:64). Hasibuan (2014:12) menyatakan, apabila sumber daya manusia tidak dilibatkan dalam perusahan, maka aktivitas perusahaan tidak akan berjalan. Karambut dan Noormijati (2012) menyatakan tingginya komitmen organisasional akan berdampak pada pegawai yang akan memberikan usaha terbaik kepada organisasi, bahkan bersedia mengerjakan sesuatu melampaui batas yang diwajibkan organisasi. Pegawai dengan komitmen tinggi pada organisasinya dapat mendorong kesuksesan organisasi pada pencapaian setiap sasaran yang telah ditetapkan (Suardani dan Supartha, 2018).

Komitmen organisasional akan menunjukkan bagaimana kemauan seorang pegawai dalam melanjutkan pekerjaannya, setia kepada organisasinya, usaha ekstra yang digunakan untuk pencapaian tujuan dan pengidentifikasian pegawai dalam memenuhi tujuan organisasi (Haq et al., 2014). Pegawai yang memiliki komitmen terhadap organisasinya akan berperilaku, seperti mempertimbangkan tujuan dan manfaat organisasi seperti milik sendiri, mengambil risiko untuk organisasi dan keinginan untuk tetap berada di dalam organisasi sehingga dengan menurunya tingkat keinginan pegawai untuk mengundurkan diri akan dapat meningkatkan komitmen pegawai dan efektivitas perusahaan (Turgut et al., 2012)

Wanjiku (2016) menyatakan bahwa pemberdayaan pegawai dapat mempengaruhi komitmen organisasional. Hutagaol (2014) menyatakan bahwa pemberdayaan bagi para pegawai akan menimbulkan pengaruh positif terhadap komitmen organisasional, hal ini dapat diindikasikan oleh meningkatnya rasa tanggung jawab dan kewajiban pegawai untuk menyelesaikan tugas sebaikbaiknya untuk mencapai tujuan perusahaan. Kuo et al. (2010) menyatakan pemberdayaan merupakan cara untuk mendorong dan meningkatkan pengambilan keputusan pegawai di tingkat bawah yang dapat memperkaya pengalaman kerja pegawai. Pemberdayaan pegawai bisa dikatakan sebagai partisipasi manajemen yang melibatkan pegawai untuk bertanggung jawab di dalam proses kerjanya (Elnaga dan Imran, 2014).

Komitmen Organisasional juga dipengaruhi oleh Dukungan Organisasi (Adhika dan Riana, 2016). Eisenberger et al., (2017:54) mengatakan bahwa elemen yang mempengaruhi perilaku pegawai adalah dukungan organisasi dimana mereka bekerja, dukungan positif dari pimpinan dan segenap pegawai akan menciptakan situasi kerja yang kondusif. (Darmawan, 2013) mengemukakan bahwa persepsi dukungan organisasi fokus pada perlakuan yang menguntungkan pegawai dan keterlibatan pegawai dalam hubungan timbal balik dengan 
organisasi. Persepsi dukungan organisasi adalah salah satu kunci dalam membangun komitmen organisasional.

Ardana dkk. (2012:153) menyatakan bahwa kompensasi adalah segala sesuatu yang diterima oleh pegawai sebagai balas jasa atas kontribusinya kepada organisasi atau perusahaan. Pemberian kompensasi kepada pegawai harus sangat diperhatikan agar tidak terjadi kecemburuan sosial antara pegawai. Pemberian kompensasi yang tidak adil secara tidak langsung akan dapat menyebabkan menurunnya komitmen organisasional. Labri (2014) mengatakan kompensasi adalah sebuah konsep yang tidak biasanya diberikan perhatian banyak di suatu organisasi.

Penelitian ini dilakukan pada salah satu Kementerian di Bali yaitu Kementerian PUPR Balai Wilayah Sungai Bali-Penida. Lokasi Kementerian beralamat di Jalan Kapten Tjok Agung Tresna No.9 Renon Denpasar. Jumlah pegawai kesluruhan pada Kementerian PUPR Balai Wilayah Sungai Bali-Penida sebanyak 345 pegawai. Jumlah pegawai yang bestatus PNS sebanyak 172 pegawai, dan jumlah pegawai berstatus kontrak/Non PNS sebanyak 173 pegawai. Subyek pada penelitian ini yaitu pegawai yang berstatus Non PNS/pegawai kontrak dengan sampel sebanyak 65 orang pegawai kontrak. Berdasarkan hasil wawancara pada 15 orang pegawai kontrak adapun permasalahan yang sering dihadapi terkait Komitmen Organisasional. Hal ini dapat dilihat pada Tabel 1.

Tabel 1.

\section{Permasalahan terkait Komitmen Organisasional pada Kementerian PUPR} Balai Wilayah Sungai Bali-Penida

\begin{tabular}{|c|c|c|}
\hline $\begin{array}{c}\text { Indikator } \\
\text { Komitmen } \\
\text { Organisasional }\end{array}$ & Contoh Permasalahan & $\begin{array}{l}\text { Jumlah } \\
\text { Pegawai } \\
\text { Kontrak }\end{array}$ \\
\hline $\begin{array}{l}\text { Affective } \\
\text { Commitment }\end{array}$ & $\begin{array}{l}\text { Pegawai kontrak belum merasa bangga memiliki } \\
\text { organisasi dan belum adanya ikatan emosional } \\
\text { pegawai kontrak dengan organisasi. }\end{array}$ & 6 \\
\hline $\begin{array}{l}\text { Continuance } \\
\text { Commitment }\end{array}$ & $\begin{array}{l}\text { Pegawai kontrak merasa kehidupannya terganggu jika } \\
\text { berhenti dari organisasi karena banyak organisasi } \\
\text { yang menawarkan gaji yang lebih besar, namun } \\
\text { kenyataannya belum tentu lebih besar setelah pegawai } \\
\text { kontrak keluar dari organisasi. }\end{array}$ & 5 \\
\hline $\begin{array}{l}\text { Normative } \\
\text { Commitment }\end{array}$ & $\begin{array}{l}\text { Pegawai kontrak belum merasa wajib memiliki } \\
\text { organisasi serta kurangnya tanggung jawab dalam } \\
\text { menyelesaikan pekerjaan. }\end{array}$ & 4 \\
\hline
\end{tabular}

Tabel 1. dapat dilihat bahwa permasalahan yang terjadi pada 15 orang pegawai kontrak mempunyai komitmen rendah pada Kementerian PUPR Balai Wilayah Sungai Bali-Penida. Hal tersebut dilihat dari menurunnya keaktifan dalam bekerja dengan adanya beberapa pegawai kontrak yang tidak memiliki inisiatif dan kurang bertanggung jawab terhadap pekerjaannya. Pegawai kontrak cenderung bermalas-malasan dalam bekerja dan mereka lebih cenderung untuk menyelesaikan suatu pekerjaan jika atasan sudah meminta hasil pekerjaannya dan dikerjakan dalam keadaan sudah mendesak tentu hasilnya kurang maksimal. 
Pegawai kontrak belum mempunyai keterikatan emosional dengan organisasi, karena pegawai kontrak merasa jika organisasi mengalami kemunduran mereka tidak akan dirugikan. Ini menandakan bahwa pegawai kontrak tersebut belum mempunyai komitmen terhadap organisasi tempatnya bekerja.

Berdasarkan hasil observasi pada Kementerian PUPR Balai Wilayah Sungai Bali-Penida, diperoleh keterangan bahwa permasalahan yang berkaitan dengan rendahnya komitmen organisasional disebabkan karena kurangnya pemberdayaan pegawai yang ditandai dengan kondisi organisasi terhadap pegawai kontrak kurang memberdayakan pegawai. Organisasi belum memberikan tanggung jawab dan kebebasan kepada pegawai kontrak bagaimana cara mereka menyelesaikan suatu pekerjaan agar hasil kerja sesuai dengan apa yang telah direncanakan. Organisasi dalam mengambil keputusan belum melibatkan peran serta pegawai kontrak, baik dari perencanaan pekerjaan sampai mengevaluasi pekerjaannya. Pegawai kontrak disini hanya bertugas menjalankan perintah dari atasan saja, hal ini dapat menyebabkan menurunnya komitmen organisasional pegawai kontrak karena merasa kurang diberdayakan.

Dukungan organisasi juga menjadi penyebabnya rendahnya komitmen organisasional pegawai, dapat dilihat dari kurangnya respon pemimpin terhadap pegawai kontrak dalam menyelesaikan suatu pekerjaan yang di anggap berat. Pimpinan dan organisasi belum memberikan secara penuh kepada pegawai kontrak dalam memberikan bantuan dan arahan dalam bekerja, yang mengakibatkan pegawai merasa kesulitan dalam menyelesaikan pekerjaan sendiri sehingga hal ini menimbulkan kurangnya dukungan yang diberikan oleh pimpinan maupun organisasi.

Pemberian kompensasi kepada pegawai kontrak tidak adil, dapat dilihat dari kompensasi yang diberikan perusahaan kepada pegawai kontrak sama rata, baik kepada pegawai kontrak yang mempunyai prestasi tinggi dan pegawai kontrak yang mempunyai prestasi rendah. Dari permasalahan tersebut berdampak terhadap tingkat komitmen organisasional pegawai yang menurun berupa adanya beberapa pegawai yang meninggalkan perusahannya dikarenakan tidak kuat terhadap tekanan yang dihadapi diperusahaan.

Kajian empiris terkait pemberdayaan pegawai, dukungan organisasi dan kompensasi terhadap komitmen organisasional, penelitian ini membahas : 1). Bagaimana pengaruh pemberdayaan pegawai terhadap komitmen organisasional? ; 2). Bagaimana pengaruh dukungan organisasi terhadap komitmen organisasional?; 3).Bagaimana pengaruh kompensasi terhadap komitmen organisasional?.

Tujuan penelitian adalah : 1). Untuk mengetahui dan menjelaskan peengaruh pemberdayaan pegawai terhadap komitmen organisasional ; 2). Untuk mengetahui dan menjelaskan pengaruh dukungan organisasi terhadap komitmen organisasional ; 3). Untuk mengetahui dan menjelaskan pengaruh kompensasi terhdap komitmen organisasional.

Dalam penelitian ini di dasarkan oleh Teori yaitu Social Exchange Theory yang digagas oleh Blau pada tahun 1964. Teori ini menyatakan bahwa pegawai cenderung mengembangkan hubungan berkualitas tinggi berdasarkan pada siapa mereka berinteraksi, bagaimana mereka berinteraksi, dan bagaimana pengalaman 
mereka (Blau, 1964). Fung et al. (2012) menyatakan bahwa teori pertukaran sosial merupakan pandangan pegawai ketika mereka telah diperlakukan dengan baik oleh organisasi, mereka akan cenderung untuk melakukan balas budi terhadap organiasi dengan bersikap dan berperilaku lebih positif terhadap organisasi.

Pemberdayaan pegawai adalah pemberian tanggung jawab dan wewenang dari atasan kepada pegawai, yang melibatkan adanya "sharing" informasi dan pengetahuan untuk memandu dan mengembangkan pegawai dalam bertindak sesuai dengan tujuan organisasi yang dinyatakan dalam satuan skor sebagai tolok ukurnya Hasibuan (2014:112). Ghosh (2013) menyatakan pemberdayaan pegawai memberi kontribusi terhadap pencapaian tujuan organisasi, sehingga pemberdayaan pegawai yang tepat dan efektif adalah sebuah kebutuhan. Hasil penelitian Suardani dan Supartha (2018) mengungkapkan pemberdayaan berpengaruh positif dan signifikan terhadap komitmen organisasional. Adrika dan Ardana (2017) menyatakan Pemberdayaan Karyawan berpengaruh positif dan signifikan terhadap komitmen organisasional PT. Raditya Dewata Perkasa. Hal ini berarti bahwa semakin baik pemberdayaan maka komitmen organisasional akan semakin kuat. Wanjiku (2016) menyatakan bahwa pemberdayaan karyawan berpengaruh positif dan signifikan terhadap komitmen organisasional. Setiawan dan Piartrini (2018) menyatakan bahwa Pemberdayaan karyawan berpengaruh positif dan signifikan terhadap komitmen organisasional pada Villa Ocean Blue. Widayanti dan Sariyathi (2016) mengatakan Pemberdayaan karyawan memiliki pengaruh positif terhadap komitmen organisasi pada CV. Akar Daya Mandiri Cabang Badung.

$\mathrm{H}_{1}$ : Pemberdayaan Pegawai Berpengaruh Positif dan Signifikan Terhadap Komitmen Organisasional

Chiang dan Hsieh (2012) menyatakan bahwa dukungan organisasi mampu meningkatkan dan memberikan efektifitas pada peningkatan komitmen organisasional anggota, tentu saja komitmen organisasional akan menghasilkan pengaruh yang sangat signifikan terhadap organisasi. Hasil penelitian Fahrizal dan Utama (2017) menyatakan bahwa Persepsi dukungan organisasi berpengaruh positif dan signifikan terhadap komitmen organisasional pada hotel kajane Mua Ubud. Damayanti (2017) mengatakan Dukungan Organisasi berpengaruh signfikan terhadap komitmen organisasi karyawan Universitas Narotama Surabaya. Wijaya dan Yuniawan (2017) menyatakan bahwa Dukungan Organisasi memiliki pengaruh yang positif dan signifikan terhadap variabel Komitmen Organisasi pada PT. Pos Indonesia Processing Center Semarang. Nurhayati (2015) menyatakan bahwa dukungan organisasi berpengaruh positif dan signifikan terhadap komitmen organisasional pada guru taman kanak-kanak di kecamatan sanden. Dewi dan Rahyuda, 2015 menyatakan bahwa dukungan organisasi berpengaruh positif dan signifikan terhadap komitmen organisasional.

$\mathrm{H}_{2}$ : Dukungan Organisasi Berpengaruh Positif dan Signifikan Terhadap Komitmen Organisasional.

Pemberian kompensasi dalam suatu organisasi perlu diatur dengan baik sehingga sistem kompensasi dapat dikembangkan di tempat kerja dengan baik. Selain itu, jumlah kompensasi yang diberikan bagi seorang pegawai tergantung pada tingkat kontribusi energi dan pemikiran yang diberikan kepada organisasi 
Labri (2014). Hasil penelitian Pratama dkk. (2016) menyatakan bahwa kompensasi berpengaruh positif terhadap komitmen organisasional. Nurtika dan Sariyathi (2018) menyatakan bahwa Kompensasi Finansial berpengaruh. Novita (2018) menyatakan bahwa kompensasi berpengaruh terhadap komitmen organisasional karyawan koperasi maahasiswa universitas negerti yogyakarta. Saifunurmazah (2018) pada penelitiannya mengatakan kompensasi berpengaruh positif terhadap komitmen organisasional pada PT.Bank Mandiri Syariah Tbk, Semarang. Syofiana (2018) menyatakan bahwa kompensasi instrinsik berpengaruh terhadap komitmen organisasional pada Lembaga Penjaminan Mutu Pendidikan Provinsi Sumatera Utara.

$\mathrm{H}_{3}$ : Kompensasi Berpengaruh Positif dan Signifikan Terhadap Komitmen Organisasional.

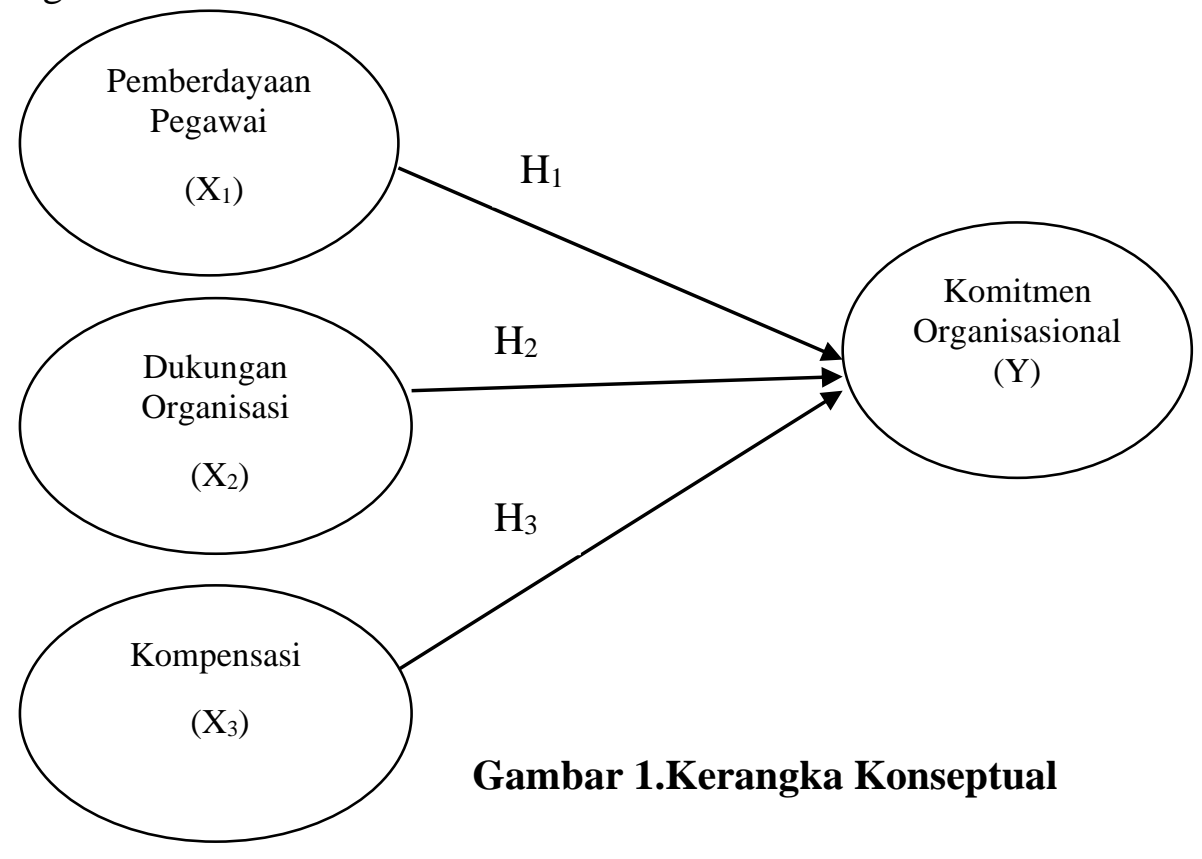

\section{METODE PENELITIAN}

Jenis penelitian ini apabila dilihat dari variabel serta keterikatan yang akan diteliti, maka dapat dikategorikan sebagai jenis penelitian kuantitatif asosiatif yang bertujuan untuk mengetahui hubungan antara dua variabel atau lebih (Sugiyono, 2017:20). Lokasi penelitian ini pada Kementerian Pekerjaan Umum dan Perumahan Rakyat Balai Wilayah Sungai Bali-Penida. Berlokasi di Jalan Kapten Tjok Agung Tresna No.9 Renon Denpasar. Jumlah populasi pada penelitian ini sebanyak 173 pegawai. Penentuan sampel menggunakan teknik simple random sampling adalah teknik pengambilan sampel dari anggota populasi yang dilakukan secara acak tanpa memperhatikan strata yang ada dalam populasi itu. Sugiyono (2017:402) sampel adalah bagian dari jumlah dan karakteristik yang dimiliki oleh populasi tersebut. Jumlah sampel sebanyak 65 responden yang berstatus sebagai pegawai kontrak ditentukan dengan menggunakan pendekatan Slovin. 
Indikator untuk mengukur komitmen organisasional menurut Meyer dan Allen, 1991 antara lain: 1) Affective commitment (Komitmen afektif) merupakan keinginan pegawai untuk dapat tetap menjadi bagian dalam sebuah organisasi, 2) Continuance commitment (Komitmen berkelanjutan) merupakan komitmen pegawai untuk tidak akan meninggalkan organisasi tempatnya bernaung karena adanya kesadaran akan mendapatkan kerugian jika pegawai tersebut meninggalkan organisasi, 3) Normative commitment (Komitmen normatif) merupakan komitmen seorang pegawai kepada organisasi tempatnya bekerja karena pegawai tersebut memiliki rasa tanggung jawab yang besar dalam bekerja.

Terdapat empat indikator mengenai pemberdayaan pegawai yang dikemukakan oleh Chiang dan Hsieh (2012) antara lain: 1) Meaning, mengacu pada sejauh mana pegawai memiliki rasa tujuan atau hubungan pribadi tentang pekerjaannya, 2) Competence, mengacu pada sejauh mana pegawai percaya bahwa ia memiliki keterampilan dan kemampuan yang diperlukan untuk melakukan pekerjaan mereka dengan baik, 3) Self-determination, mengacu pada sejauh mana pegawai memiliki rasa kebebasan tentang bagaimana individu menyelesaikan pekerjaannya didalam perusahaan, 4) Impact, mengacu pada sejauh mana pegawai percaya bahwa ia dapat memengaruhi sistem organisasi dimana ia bekerja.

Menurut Robbins (2010:103) beberapa indikator yang digunakan sebagai alat ukur dukungan organisasi sebagai berikut: 1) Kesejahteraan, diukur dari persepsi pegawai bahwa organisasi peduli pada kesejahteraan lingkungan, 2) Tugas, diukur dari persepsi pegawai terhadap respon organisasi dalam membantu pegawai menyelesaikan tugas yang dianggap berat, 3) Respon pemimpin, diukur dari persepsi pegawai terhadap respon pemimpin dalam mendukung kelancaran kerja bawahannya, 4) Kedekatan, diukur dari persepsi pegawai terhadap hubungan antar orang yang ada didalam organisasi seperti hubungan kerja antara sesama pegawai dan pegawai dengan pimpinan guna memberikan suasana kondusif dalam bekerja.

Menurut Sedarmayanti (2009:242) beberapa indikator yang bisa digunakan untuk mengukur kompensasi adalah sebagai berikut: 1) Kompensasi diukur dari tuntutan pekerjaan yaitu besar kecilnya kompensasi yang diberikan oleh perusahaan kepada pegawai sesuai dengan berat ringannya pekerjaan yang dikerjakan, 2) Kompensasi diukur dari tingkat keterampilan yaitu pegawai yang mengerjakan pekerjaan dengan tingkat keterampilan yang tinggi menerima kompensasi yang lebih besar, 3) Kompensasi diukur dari sebuah penghargaan yaitu pegawai diberikan kompensasi atas prestasi yang diraihnya diperusahaan, 4) Kesesuaian kompensasi dengan pegawai diorganisasi lain yaitu pegawai menerima kompensasi lebih besar atau sebanding dengan pegawai di perusahaan lain dengan jenis dan tingkat pekerjaan yang sama, 5) Kesesuaian gaji dengan standar pengupahan yaitu besarnya gaji yang diterima oleh pegawai sesuai dengan UMK (Upah Minimum Kabupaten) atau standar pengupahan yang berlaku.

Variabel dalam penelitian ini meliputi pemberdayaan pegawai, dukungan organisasi dan kompensasi sebagai variabel bebas dan komitmen organisasional sebagai variabel terikat. Metode pengumpulan data dalam penelitian ini observasi, wawancara, dan survey. Sumber data yang digunakan yaitu sumber primer dan 
sumber sekunder. Sumber Primer adalah sumber data yang langsung memberikan data kepada pengumpul data (Sugiyono, 2017:402). Sumber sekunder yaitu sumber data yang tidak langsung memberikan data kepada pengumpul data, misalnya lewat orang lain atau lewat dokumen (Sugiyono, 2017:402). Jenis data pada pada penelitian ini data kuantitatif yaitu data yang dapat dinyatakan dalam bentuk angka, dan memiliki satuan hitung. Data yang digunakan dalam penelitian ini adalah jumlah pegawai dan data yang langsung dapat dari pegawai dengan cara penyebaran kuesioner Sugiyono (2017:23). Data kualitatif yaitu data yang berbentuk kata, penjelasan, skema dan gambar. Data yang digunakan dalam penelitian ini adalah sejarah singkat organisasi, struktur, dan uraian tugas Sugiyono (2017:25).

Pengujian instrumen penelitian menggunakan uji validitas dan uji reliabilitas. Uji validitas dilakukan dengan mengkorelasikan antara skor faktor atau butir dengan skor total, bila korelasi setiap faktor tersebut bernilai positif dan besarnya diatas 0,30 dan signifikan maka instrumen tersebut merupakan instrumen yang valid (Sugiyono, 2017:203). Uji Reliabilitas dilakukan untuk menunjukkan sejauh mana suatu alat pengukuran dapat dipercaya atau dapat diandalkan, dengan kata lain uji reliabilitas menunjukkan tingkat konsistensi suatu alat pengukur. Pengujian statistik dengan menggunakan teknik statistik Cronbach's Alpha, instrumen dikatakan reliabel apabila memiliki nilai Cronbach's Alpha tiap variabel lebih besar dari 0,60 (Sugiyono, 2017:209).

Teknik Analisis Data yang digunakan dalam penelitian ini adalah metode analisis regresi linear berganda. Sebelum analisis regresi dilakukan atau diinterpretasikan terlebih dahulu dilakukan uji asumsi klasik agar hasil perhitungan dapat diinterprestasikan dengan akurat. Uji Asumsi Klasik yang meliputi Uji Normalitas, Uji Multikolineritas, dan Uji Heteroskedastisitas. Uji kelayakan model yang terdiri dari Uji $F$ dan Uji Koefisien Determinasi $\left(\mathrm{R}^{2}\right)$ Utama (2016:79). Teknik analisis yang teakhir digunakan yaitu uji hipotesis (ttest) digunakan untuk menguji signifikansi pengaruh variabel independen Pemberdayaan Pegawai $\left(\mathrm{X}_{1}\right)$, Dukungan Organisasi $\left(\mathrm{X}_{2}\right)$, Kompensasi $\left(\mathrm{X}_{3}\right)$ secara parsial terhadap variabel dependen Komitmen Organisasional (Y). Pengukuran terhadap butir-butir pernyataan dalam kuesioner menggunakan skala likert.

\section{HASIL DAN PEMBAHASAN}

Penelitian ini menggunakan 65 orang pegawai kontrak pada Kementerian PUPR Balai Wilayah Sungai Bali-Penida sebagai responden sesuai dengan ukuran sampel yang digunakan. Berdasarkan hasil penelitian dari penyebaran kuesioner dengan karakteristik responden dijelaskan secara umum dilihat dari jenis kelamin, tingkat pendidikan, masa kerja dan umur. Adapun karakteristik responden dapat ditunjukkan pada Tabel 2.

Kriteria jenis kelamin responden dapat digunakan sebagai acuan untuk mengetahui perbandingan jumlah pegawai kontrak laki-laki dan perempuan pada suatu perusahaan. Berdasarkan Tabel 2 dapat dilihat bahwa yang berjenis kelamin laki-laki dan perempuan tidak jauh berbeda, dimana pegawai kontrak laki-laki berjumlah 36 orang $(55,4 \%)$ sedangkan jumlah pegawai kontrak perempuan 
berjumlah 29 orang $(44,6 \%)$. Hal ini menunjukkan bahwa pegawai kontrak lakilaki dan perempuan mempunyai kewajiban yang sama untuk bekerja dan menghasilkan uang demi memenuhi kebutuhan hidup.

Tabel 2.

Karakteristik Responden

\begin{tabular}{|c|c|c|c|c|}
\hline No & Variabel Karakteristik & Klasifikasi & Jumlah (Orang) & Persentase $(\%)$ \\
\hline 1 & \multirow{2}{*}{ Jenis Kelamin } & Laki* & 36 & 55.4 \\
\hline \multirow[t]{2}{*}{2} & & Perempuan & 29 & 44.6 \\
\hline & \multirow{4}{*}{ Pendidikan } & & 65 & 100 \\
\hline 1 & & SMA/SMK & 16 & 24.6 \\
\hline 2 & & S1 & 47 & 72.3 \\
\hline \multirow[t]{2}{*}{3} & & S2 & 2 & 3.1 \\
\hline & Juml & & 65 & 100 \\
\hline 1 & \multirow{4}{*}{ Masa Kerja } & 1-5 Tahun & 18 & 27.7 \\
\hline 2 & & 6-10 Tahun & 35 & 53.8 \\
\hline 3 & & 11-15 Tahun & 9 & 13.8 \\
\hline \multirow[t]{2}{*}{4} & & 16-20 Tahun & 3 & 4.6 \\
\hline & Juml & & 65 & 100 \\
\hline 1 & \multirow{4}{*}{ Umur } & 18-27 Tahun & 11 & 16.9 \\
\hline 2 & & 28-37 Tahun & 33 & 50.8 \\
\hline 3 & & 38-47 Tahun & 12 & 18.5 \\
\hline \multirow[t]{2}{*}{4} & & 48-57 Tahun & 9 & 13.8 \\
\hline & Juml & & 65 & 100 \\
\hline
\end{tabular}

Sumber: Data diolah, 2019

Tabel 2. menunjukkan bahwa pendidikan terakhir dari pegawai kontrak adalah S1 atau Sarjana yang paling banyak yaitu 47 orang $(72,3 \%)$ untuk SMA/SMK sebanyak 16 orang $(24,6 \%)$ dan untuk S2 atau Pascasarjana paling sedikit yaitu 2 orang $(3,1 \%)$. Ini berarti tingkat pendidikan pegawai kontrak dapat dikatakan baik dengan didominasi dengan pendidikan terakhir S1. Namun ada baiknya pendidikan terakhir pegawai kontrak S2 agar dapat meningkatkan kualitas diri dan menambah pengetahuan. Perusahaan perlu memikirkan kesejahteraan pegawai kontrak agar tingkat komitmen pegawai kontrak semakin meningkat, sehingga kinerja yang dihasilkan juga semakin bagus.

Tabel 2. menunjukkan bahwa karakteritik masa kerja terdapat 4 bagian, masa kerja 1-5 tahun sebanyak 18 orang $(27,7 \%)$, masa kerja 6-10 tahun sebanyak 35 orang $(53,8 \%)$, masa kerja $11-15$ tahun sebanyak 9 orang $(13,8 \%)$ dan masa kerja 16-20 tahun sebanyak 3 orang $(4,6 \%)$. Hal ini berarti pegawai kontrak mempunyai kemauan dan keinginan untuk bertahan pada perusahaan dan memberikan yang terbaik kepada perusahaan agar nantinya dapat diangkat menjadi Pegawai Negeri Sipil.

Tabel 2. menunjukkan bahwa umur pegawai kontrak bervariasi dan terdapat 4 bagian, dimana umur 18-27 sebanyak 11 orang (16,9\%), 28-37 tahun sebanyak 33 orang $(50,8 \%), 38-47$ tahun sebanyak 12 orang $(18,5 \%)$ dan $48-57$ tahun sebanyak 9 orang $(13,8 \%)$. Ini berarti pegawai kontrak didominasi oleh umur 2837 tahun, artinya pada umur tersebut semangat dan komitmen pegawai kontrak masih tinggi.

Suatu instrumen dikatakan valid atau layak digunakan dalam pengujian hipotesis apabila memiliki koefisien korelasi antara butir dengan skor total dalam 
instrumen tersebut bernilai positif dan besarnya diatas 0,30 dan signifikan dengan tingkat kesalahan Alpha 0,05. Tabel 3. berikut menyajikan hasil uji validitas instrumen penelitian.

Tabel 3.

Hasil Uji Validitas Instumen Penelitian

\begin{tabular}{cccccc}
\hline Variabel & Indikator & $\begin{array}{c}\text { Koefisien } \\
\text { Korelasi }\end{array}$ & $\begin{array}{c}\text { Sig. } \\
\text { (2-tailed })\end{array}$ & $\begin{array}{c}\text { Alpha } \\
\text { Cronbach's }\end{array}$ & Keterangan \\
& Y1 & 0,695 & 0,000 & 0,30 & Valid \\
& Y2 & 0,709 & 0,000 & 0,30 & Valid \\
Komitmen & Y3 & 0,833 & 0,000 & 0,30 & Valid \\
Organisasional & Y4 & 0,824 & 0,000 & 0,30 & Valid \\
(Y) & Y6 & 0,854 & 0,000 & 0,30 & Valid \\
& Y7 & 0,827 & 0,000 & 0,30 & Valid \\
& Y8 & 0,930 & 0,000 & 0,30 & Valid \\
& Y9 & 0,823 & 0,000 & 0,30 & Valid \\
Pemberdayaan & X1.1 & 0,853 & 0,000 & 0,30 & Valid \\
Pegawai & X1.2 & 0,762 & 0,000 & 0,30 & Valid \\
(X1) & X1.3 & 0,833 & 0,000 & 0,30 & Valid \\
& X1.4 & 0,826 & 0,000 & 0,30 & Valid \\
& X1.5 & 0,839 & 0,000 & 0,30 & Valid \\
& X1.6 & 0,821 & 0,000 & 0,30 & Valid \\
& X2.1 & 0,729 & 0,000 & 0,30 & Valid \\
& X2.2 & 0,812 & 0,000 & 0,30 & Valid \\
Xukungan & X2.3 & 0,805 & 0,000 & 0,30 & Valid \\
Organisasi & X2.4 & 0,862 & 0,000 & 0,30 & Valid \\
(X2) & X2.5 & 0,886 & 0,000 & 0,30 & Valid \\
& X2.6 & 0,865 & 0,000 & 0,30 & Valid \\
& X3.1 & 0,856 & 0,000 & 0,30 & Valid \\
Xompensasi & X3.2 & 0,847 & 0,000 & 0,30 & Valid \\
& X3.3 & 0,814 & 0,000 & 0,30 & Valid \\
& X3.4 & 0,881 & 0,000 & 0,30 & Valid \\
& & 0,832 & 0,000 & 0,30 & Valid \\
\hline
\end{tabular}

Sumber: Data diolah, 2019

Hasil uji validitas pada Tabel 3. menunjukkan bahwa seluruh instrumen penelitian yang digunakan untuk mengukur variabel Komitmen Organisasional, Pemberdayaan Pegawai, Dukungan Organisasi dan Kompensasi memiliki nilai koefisien korelasi dengan skor total seluruh item pernyataan lebih besar dari 0,30 dengan signifikansi kurang dari 0,05 . Hal ini berarti bahwa butir-butir pernyataan dalam instrumen penelitian tersebut valid dan layak digunakan sebagai instrumen penelitian.

Uji Reliabilitas dilakukan untuk menunjukkan sejauh mana suatu alat pengukur dapat dipercaya atau dapat diandalkan. Pengujian statistik dengan menggunakan teknik statistik Cronbach's Alpha, instrumen dikatakan reliabel apabila memiliki nilai Cronbach's Alpha tiap variabel lebih besar dari 0,60.

Tabel 4.

Hasil Uji Reliabilitas Instrumen Penelitian 


\begin{tabular}{clcc}
\hline No & \multicolumn{1}{c}{ Variabel } & $\begin{array}{c}\text { Cronbach's } \\
\text { Alpha }\end{array}$ & Keterangan \\
\hline 1. & Komitmen Organisasional (Y) & 0,929 & Reliabel \\
2. & Pemberdayaan Pegawai (X1) & 0,908 & Reliabel \\
3. & Dukungan Organisasi (X2) & 0,904 & Reliabel \\
4. & Kompensasi (X3) & 0,897 & Reliabel \\
\hline
\end{tabular}

Sumber: Data diolah, 2019

Hasil uji reliabilitas yang disajikan dalam Tabel 4 menunjukkan bahwa seluruh instrumen penelitian memiliki koefisien Cronbach's Alpha lebih dari 0,60. Pada uji reliabilitas pada instrumen penelitian ini dapat dinyatakan bahwa seluruh variabel telah memenuhi syarat reliabilitas atau kehandalan sehingga layak dan dapat digunakan untuk melakukan penelitian.

Variabel komitmen organisasional diukur dengan menggunakan 9 item pernyataan yang berhubungan dengan komitmen pegawai kontrak terhadap perusahaan.

Tabel 5.

Jawaban Responden terhadap Variabel Komitmen Organisasional (Y)

\begin{tabular}{|c|c|c|c|c|c|c|c|c|c|}
\hline \multirow{2}{*}{ No } & \multirow{2}{*}{ Pernyataan } & \multicolumn{5}{|c|}{ Skor Jawaban } & \multirow{2}{*}{$\begin{array}{l}\text { Jumlah } \\
\text { Skor }\end{array}$} & \multirow{2}{*}{$\begin{array}{l}\text { Rata } \\
\text { Rata }\end{array}$} & \multirow{2}{*}{ Kriteria } \\
\hline & & 1 & 2 & 3 & 4 & 5 & & & \\
\hline 1. & $\begin{array}{l}\text { Saya merasa } \\
\text { emosional dengan perusahaan ini }\end{array}$ & 0 & 6 & 23 & 30 & 6 & 231 & 3,55 & Baik \\
\hline 2. & $\begin{array}{l}\text { Saya merasa menjadi bagian dari } \\
\text { keluarga di perusahaan ini. }\end{array}$ & 0 & 2 & 17 & 37 & 9 & 248 & 3,82 & Baik \\
\hline 3. & $\begin{array}{l}\text { Saya berkeinginan } \\
\text { menghabiskan } \\
\text { perusahaan ini. }\end{array}$ & 1 & 8 & 20 & 24 & 12 & 233 & 3,58 & Baik \\
\hline 4. & $\begin{array}{l}\text { Saya merasa kehidupan saya akan } \\
\text { terganggu apabila berhenti di } \\
\text { perusahaan ini. }\end{array}$ & 1 & 8 & 18 & 32 & 6 & 229 & 3,52 & Baik \\
\hline 5. & $\begin{array}{l}\text { Saya merasa akan rugi jika } \\
\text { meninggalkan perusahaan ini. }\end{array}$ & 1 & 8 & 18 & 27 & 11 & 234 & 3,60 & Baik \\
\hline 6. & $\begin{array}{l}\text { Saya merasa ingin tetap bekerja di } \\
\text { perusahaan ini karena merupakan } \\
\text { kebutuhan. }\end{array}$ & 2 & 6 & 13 & 32 & 12 & 241 & 3,71 & Baik \\
\hline 7. & $\begin{array}{l}\text { Saya bersedia dilibatkan dalam } \\
\text { kegiatan kerja demi kepentingan } \\
\text { perusahaan }\end{array}$ & 0 & 6 & 20 & 27 & 12 & 240 & 3,69 & Baik \\
\hline 8. & $\begin{array}{l}\text { Saya tidak akan menerima tawaran } \\
\text { dari perusahaan lain untuk } \\
\text { meninggalkan perusahaan ini. }\end{array}$ & 2 & 9 & 24 & 23 & 7 & 219 & 3,37 & Netral \\
\hline 9. & $\begin{array}{l}\text { Saya akan tetap setia, memiliki } \\
\text { rasa loyalitas } \\
\text { perusahaanini. }\end{array}$ & 0 & 9 & 15 & 24 & 17 & 244 & 3,75 & Baik \\
\hline & Rata-Rata & & & & & & & 3,62 & Baik \\
\hline
\end{tabular}

Sumber: Data diolah, 2019

Data pada Tabel 5. menunujukkan bahwa jumlah responden pada variabel Komitmen Organisasional secara keseluruhan memiliki rata-rata sebesar 3,62 yang berarti komitmen pegawai kontrak pada Kementerian PUPR Balai Wilayah Sungai Bali-Penida tergolong dalam kriteria baik. Nilai rata-rata tertinggi jawaban 
responden sebesar 3,82, ini berarti pegawai kontrak merasa sudah nyaman pada perusahaan dan perusahaan juga sudah mau merangkul dan menganggap semua pegawai adalah keluarga dalam menyelesaikan pekerjaan demi mencapai tujuan perusahaan. Selanjutnya nilai rata-rata terendah jawaban sebesar 3,37, ini berarti perusahaan tetap harus meningkatkan kenyamanan dan keadilan pegawai kontrak dalam menyelesaikan suatu pekerjaan agar pegawai kontrak tidak meninggalkan perusahaan.

Pemberdayaan pegawai diukur dengan menggunakan 6 item pernyataan yang berhubungan dengan bagaimana perusahaan ataupun atasan memberdayakan pegawai kontrak. Jawaban responden mengenai masing-masing pernyataan pada variabel pemberdayaan pegawai secara rinci dapat dilihat pada Tabel 6 .

Tabel 6.

Jawaban Responden terhadap Variabel Pemberdayaan Pegawai (X1)

\begin{tabular}{|c|c|c|c|c|c|c|c|c|c|}
\hline \multirow{2}{*}{ No } & \multirow{2}{*}{ Pernyataan } & \multicolumn{5}{|c|}{ Skor Jawaban } & \multirow[t]{2}{*}{$\begin{array}{l}\text { Jumlah } \\
\text { Skor }\end{array}$} & \multirow[t]{2}{*}{ RataRata } & \multirow[t]{2}{*}{ Kriteria } \\
\hline & & 1 & 2 & 3 & 4 & 5 & & & \\
\hline 1. & $\begin{array}{l}\text { Saya mengetahui tujuan, } \\
\text { makna, tanggung jawab } \\
\text { pekerjaan pada Kementerian } \\
\text { Pekerjaan Umum }\end{array}$ & 0 & 0 & 25 & 25 & 15 & 250 & 3,85 & Baik \\
\hline 2. & $\begin{array}{l}\text { Saya memiliki kemampuan, } \\
\text { keyakinanuntuk menyelesaikan } \\
\text { pekerjaan }\end{array}$ & 0 & 2 & 22 & 34 & 7 & 241 & 3,71 & Baik \\
\hline 3. & $\begin{array}{l}\text { Saya bertanggung jawab untuk } \\
\text { hasil kerja sesuai wewenang } \\
\text { yang telah diberikan }\end{array}$ & 0 & 3 & 10 & 37 & 15 & 259 & 3,98 & Baik \\
\hline 4. & $\begin{array}{l}\begin{array}{l}\text { Saya memiliki kebebasan } \\
\text { untuk memutuskan } \\
\text { bagaiamana } \\
\text { menyelesaikan pekerjaan }\end{array}\end{array}$ & 0 & 10 & 19 & 28 & 8 & 229 & 3,52 & Baik \\
\hline 5. & 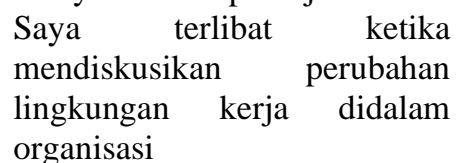 & 0 & 10 & 23 & 18 & 14 & 231 & 3,55 & Baik \\
\hline 6. & $\begin{array}{l}\text { Saya memiliki rasa percaya } \\
\text { diri dalam menyelesaikan } \\
\text { pekerjaan karena atasan } \\
\text { menghargai kemampuan saya }\end{array}$ & 0 & 4 & 18 & 32 & 11 & 245 & 3,77 & Baik \\
\hline
\end{tabular}

Sumber: Data diolah, 2019

Data pada Tabel 6. menunjukkan bahwa jawaban responden mengenai pemberdayaan pegawai memperoleh nilai rata-rata sebesar 3,73 dan masuk dalam kriteria baik. Hal tersebut menunjukkan bahwa pemberdayaan pegawai pada Kementerian PUPR Balai Wilayah Sungai Bali-Penida memiliki pimpinan dan manajemen memberikan yang terabaik kepada pegawai kontrak. Nilai rata-rata tertinggi jawaban responden sebesar 3,98, ini berarti pegawai kontrak sudah bertanggung jawab dalam menyelesaikan suatu pekerjaan yang telah diberikan 
oleh atasan. Nilai rata-rata terendah jawaban responden sebesar 3,52 dengan kriteria baik.

Variabel dukungan organisasi diukur dengan menggunakan 6 item pernyataan yang berhubungan dengan dukungan organisasi terhadap pegawai kontrak. Jawaban responden mengenai masing-masing pernyataan pada variabel dukungan organisasi secara rinci dapat dilihat pada Tabel 7.

Tabel 7.

Jawaban Responden terhadap Variabel Dukungan Organisasi (X2)

\begin{tabular}{|c|c|c|c|c|c|c|c|c|c|}
\hline \multirow[t]{2}{*}{ No } & \multirow[t]{2}{*}{ Pernyataan } & \multicolumn{5}{|c|}{ Skor Jawaban } & \multirow[t]{2}{*}{$\begin{array}{c}\text { Jumlah } \\
\text { Skor }\end{array}$} & \multirow[t]{2}{*}{$\begin{array}{l}\text { Rata } \\
\text { Rata }\end{array}$} & \multirow[t]{2}{*}{ Kriteria } \\
\hline & & 1 & 2 & 3 & 4 & 5 & & & \\
\hline 1. & $\begin{array}{l}\text { Saya senang organisasi peduli } \\
\text { pada kesejahteraan pegawai }\end{array}$ & 0 & 5 & 21 & 25 & 14 & 243 & 3,74 & Baik \\
\hline 2. & $\begin{array}{l}\text { Saya senang organisasi mau } \\
\text { membantu pekerjaan pegawai }\end{array}$ & 0 & 6 & 21 & 27 & 11 & 238 & 3,66 & Baik \\
\hline 3. & $\begin{array}{l}\text { Saya senang pemimpin mau } \\
\text { membantu mengatasi masalah } \\
\text { pegawai }\end{array}$ & 0 & 10 & 12 & 27 & 16 & 244 & 3,75 & Baik \\
\hline 4. & $\begin{array}{l}\text { Saya senang pemimpin mau } \\
\text { memberikan kritik saran tentang } \\
\text { pekerjaan }\end{array}$ & 0 & 5 & 18 & 31 & 11 & 243 & 3,74 & Baik \\
\hline 5. & $\begin{array}{l}\text { Saya senang rekan sesama mau } \\
\text { mendengarkan masalah dan mau } \\
\text { membantu ketika perlu bantuan }\end{array}$ & 0 & 5 & 12 & 30 & 18 & 256 & 3,94 & Baik \\
\hline 6. & $\begin{array}{l}\text { Saya senang pemimpin mau } \\
\text { mendengarkan keluh kesah } \\
\text { bawahan guna memberikan } \\
\text { suasana kondusif }\end{array}$ & 0 & 11 & 14 & 30 & 10 & 234 & 3,60 & Baik \\
\hline & Rata-Rata & & & & & & & 3,74 & Baik \\
\hline
\end{tabular}

Sumber: Data diolah, 2019

Data pada Tabel 7. menunjukkan bahwa jawaban responden mengenai dukungan organisasi memperoleh rata-rata sebesar 3,74 dan masuk dalam kriteria baik. Hal tersebut menunjukkan bahwa dukungan organisasi yang diberikan kepada pegawai kontrak sudah baik, sebaiknya lebih ditingkatkan agar pegawai kontrak merasa lebih dihargai dan akan sulit untuk meninggalkan perusahaan. Nilai rata-rata tertinggi jawaban responden sebesar 3,94. Ini menunjukkan bahwa semua pegawai mempunyai sifat keterbukaan antara sesama pegawai dan mau saling membantu jika rekan kerjanya mengamali kesulitan. Selanjutnya nilai ratarata terendah jawaban responden sebesar 3,60. Ini menunjukkan bahwa pemimpin sudah mau mendengarkan keluh kesah bawahan dengan baik, dan masih perlu ditingkatkan agar pegawai kontrak merasa nyaman di dalam perusahaan tempatnya bekerja.

Variabel kompensasi diukur dengan menggunakan 5 item pernyataan yang berhubungan dengan kompensasi yang diberikan kepada pegawai kontrak. Jawaban responden mengenai masing-masing pernyataan pada variabel kompensasi secara rinci dapat dilihat pada Tabel 8. 
Tabel 8.

Deskripsi Jawaban Responden terhadap Variabel Kompensasi (X3)

\begin{tabular}{|c|c|c|c|c|c|c|c|c|c|}
\hline \multirow[t]{2}{*}{ No } & \multirow[t]{2}{*}{ Pernyataan } & \multicolumn{5}{|c|}{ Skor .Iawaban } & \multirow[t]{2}{*}{$\begin{array}{l}\text { Jumlah } \\
\text { _Skor }\end{array}$} & \multirow[t]{2}{*}{ RataRata } & \multirow[t]{2}{*}{ Kriteria } \\
\hline & & 1 & 2 & 3 & 4 & 5 & & & \\
\hline 1. & $\begin{array}{l}\text { Saya merasa kompensasi yang } \\
\text { diberikan sudah sesuai dengan } \\
\text { berat ringannya suatu pekerjaan }\end{array}$ & 0 & 4 & 35 & 18 & 8 & 225 & 3,46 & Baik \\
\hline 2. & $\begin{array}{l}\text { Saya merasa kompensasi yang } \\
\text { diberikan sesuai dengan tingkat } \\
\text { keterampilan yang saya miliki }\end{array}$ & 0 & 17 & 23 & 18 & 7 & 210 & 3,23 & Netral \\
\hline 3. & $\begin{array}{l}\text { Saya diberikan penghargaan } \\
\text { atas prestasi yang saya miliki }\end{array}$ & 1 & 7 & 25 & 24 & 8 & 226 & 3,48 & Baik \\
\hline 4. & $\begin{array}{l}\text { Saya merasa kompensasi yang } \\
\text { diberikan sudah sesuai dengan } \\
\text { instansi lain dengan jenis dan } \\
\text { tingkat pekerjaan yang sama }\end{array}$ & 0 & 5 & 23 & 30 & 7 & 234 & 3,60 & Baik \\
\hline 5. & $\begin{array}{lr}\text { Saya merasa gaji yang } \\
\text { diberikan sudah } & \text { sesuai dengan } \\
\text { standar } & \text { pengupahan } \\
\text { kementerian lain } & \end{array}$ & 0 & 6 & 18 & 28 & 13 & 243 & 3,74 & Baik \\
\hline & Rata-Rata & & & & & & & 3,50 & Baik \\
\hline
\end{tabular}

Sumber: Data diolah, 2019

Data pada Tabel 8. menunjukkan bahwa jawaban responden mengenai variabel kompensasi memperoleh nilai rata-rata sebesar 3,50 dan masuk dalam kriteria baik. Nilai rata-rata tertinggi jawaban responden sebesar 3,74. Hal ini menunjukkan bahwa pemberian gaji pegawai kontrak susah sesuai dengan standar pengupahan yang telah ditentukan oleh Kementerian. Selanjutnya nilai rata-rata terendah jawaban responden sebesar 3,23 dengan kriteria netral. Ini menunjukkan bahwa pimpinan harus lebih memperhatikan dalam sistem pemberian kompensasi kepada pegawai kontrak dengan memperhatikan keterampilan dan prestasi yang dimiliki oleh pegawai kontrak.

Pengujian data dalam penelitian ini menggunakan teknik analisis regresi linier berganda. Hasil yang diperoleh melalui regresi linier berganda ditunjukkan pada Tabel 9.

Tabel 9. 
Hasil Analisis Regresi Linier Berganda

\begin{tabular}{lccccc}
\hline \multicolumn{1}{c}{ Model } & & & $\begin{array}{c}\text { Standardized } \\
\text { Coefficients } \\
(\text { Beta })\end{array}$ & T & Signifikansi \\
& $($ Beta $)$ & Std Error & & \\
\hline 1 (Constant) & 0,060 & 0,236 & & 0,253 & 0,801 \\
Pemberdayaan & 0,348 & 0,126 & 0,325 & 2.773 & 0,007 \\
Dukungan & 0,375 & 0,126 & 0,386 & 2.976 & 0,004 \\
Kompensasi & 0,245 & 0,106 & 0,239 & 2.319 & 0,024 \\
R & & & & & 0,895 \\
R Square & & & & & 0,801 \\
F Statistik & & & & & 0,077 \\
Signifikansi & & & & \\
\hline Sumber: Data diolah, 2019 & & & & \\
\end{tabular}

Berdasarkan hasil analisis regresi linier berganda seperti yang disajikan pada Tabel 9 maka didapat nilai unstandardized coefficients untuk variabel pemberdayaan pegawai sebesar 0,348 , variabel dukungan organisasi sebesar 0,375 dan variabel kompensasi sebesar 0,245. Maka persamaan struktural regresinya sebagai berikut.

$$
\mathrm{Y}=0,060+0,348 \mathrm{X}_{1}+0,375 \mathrm{X}_{2}+0,245 \mathrm{X}_{3}
$$

Persamaan regresi linier berganda menunjukkan bahwa terdapat tanda hubungan masing-masing variabel independen terhadap variabel dependen. Penjelasan persamaan regresi linier berganda adalah sebagai berikut.

$\mathrm{X} 1=0,348$, artinya permberdayaan pegawai memiliki pengaruh positif terhadap komitmen organisasional pada Kementerian PUPR Balai Wilayah Sungai Bali-Penida. $\mathrm{X} 2=0,375$, artinya dukungan organisasi memiliki pengaruh positif terhadap komitmen organisasional pada Kementerian PUPR Balai Wilayah Sungai Bali-Penida. X3 = 0,245, artinya kompensasi memiliki pengaruh positif terhadap komitmen organisasional pada Kementerian PUPR Balai Wilayah Sungai Bali-Penida.

Uji normalitas bertujuan untuk menguji apakah dalam residual dari model regresi yang dibuat berdistrubusi normal atau tidak. Model regresi yang baik adalah yang memiliki distribusi residual yang normal atau mendekati normal. Untuk mengetahui apakah data berdistribusi dengan normal atau tidak, dapat menggunakan Statistic Kolmogorov-Smirnov. Apabila koefisien Asymp. Sig. (2tailed) lebih besar dari 0,05 maka data tersebut dikatakan berdistribusi normal.

Tabel 10.

Hasil Uji Normalitas

\begin{tabular}{cc}
\hline & Unstandardized Residual \\
\hline $\mathrm{N}$ & 65 \\
Kolmogorov-Smirnov $Z$ & 0,544 \\
Asymp.Sig.(2-tailed) & 0,929 \\
\hline
\end{tabular}

Sumber: Data diolah, 2019

Berdasarkan hasil uji normalitas seperti yang disajikan pada Tabel 10, maka didapat nilai Kolmogorov-Smirnov (K-S) sebesar 0,544, sedangkan 
Asymp.Sig.(2-tailed) sebesar 0,929. Hasil tersebut mengindikasikan bahwa model persamaan regresi tersebut berdistribusi normal karena nilai Asymp.Sig. (2-tailed) 0,929 lebih besar dari nilai alpha 0,05 .

Uji multikolinieritas dilakukan untuk menguji apakah model regresi ditemukan adanya korelasi antara variabel bebas (independent). Model regresi yang baik seharusnya tidak terjadi korelasi antara variabel bebas atau bebas dari gejala multikolinier. Adanya multikoleniaritas dapat dilihat dari nilai tolerance atau variance inflation factor (VIF). Jika nilai tolerance lebih dari 10 persen atau VIF kurang dari 10, maka dikatakan tidak ada multikolinieritas.

Berdasarkan Tabel 11. dapat dilihat bahwa nilai tolerance dan VIF dari seluruh variabel menunjukkan bahwa nilai tolerance untuk setiap variabel lebih besar dari 0,10 dan VIF lebih lebih kecil dari 10. Hal ini berarti bahwa model regresi pengaruh pemberdayaan pegawai, dukungan organisasi dan kompensasi terhadap komitmen organisasional yang dibuat tidak terdapat gejala multikolinier, sehingga model tersebut layak digunakan untuk memprediksi.

Model regresi tidak mengandung adanya heteroskedastisitas bila nilai signifikansi variabel bebas terhadap nilai absolute residual statistic lebih besar dari 0,05 .

Tabel 11.

Hasil Uji Multikolinieritas

\begin{tabular}{lcc}
\hline \multicolumn{1}{c}{ Variabel } & Tolerance & VIF \\
\hline Pemberdayaan Pegawai $\left(\mathrm{X}_{1)}\right.$ & 0,237 & 4,216 \\
Dukungan Organisasi $\left(\mathrm{X}_{2)}\right.$ & 0,193 & 5,173 \\
Kompensasi $\left(\mathrm{X}_{3}\right)$ & 0,307 & 3,260 \\
\hline
\end{tabular}

Sumber: Data diolah, 2019

Tabel 12.

Hasil Uji Heteroskedastisitas

\begin{tabular}{lccccc}
\hline \multicolumn{1}{c}{ Model } & \multicolumn{5}{c}{$\begin{array}{c}\text { Standardized } \\
\text { Coefficients }\end{array}$} \\
& B & Std. error & Beta & T & Sig. \\
\hline 1 (Constant) & 0,595 & 0,137 & & 4,357 & 0,000 \\
Pemberdayaan & $-0,106$ & 0,073 & $-0,364$ & $-1,460$ & 0,149 \\
Dukungan & 0,037 & 0,073 & 0,140 & 0,508 & 0,613 \\
Kompensasi & $-0,026$ & 0,061 & $-0,092$ & $-0,422$ & 0,674 \\
\hline
\end{tabular}

Sumber: Data diolah, 2019

Pada Tabel 12. dapat dilihat bahwa nilai Sig. dari variabel Pemberdayaan Pegawai sebesar 0,149, Dukungan Organisasi sebesar 0,613 dan Kompensasi sebesar 0,674. Nilai signifikansi masing-masing variabel tersebut lebih besar dari 0,05 yang berarti tidak terdapat pengaruh antara variabel bebas terhadap absolute residual. Dengan demikian, model yang dibuat tidak mengandung gejala heteroskedastisitas.

Uji $\mathrm{F}$ digunakan untuk mengetahui ketetapan model penelitian mengenai Pemberdayaan Pegawai $\left(\mathrm{X}_{1}\right)$, Dukungan Organisasi $\left(\mathrm{X}_{2}\right)$ dan Kompensasi $\left(\mathrm{X}_{3}\right)$ 
sebagai variabel bebas secara bersama-sama terhadap Komitmen Organisasional (Y) sebagai variabel independent.

Tabel 13.

Hasil Analisis Uji Kelayakan Model

\begin{tabular}{lccccc}
\hline Model & $\begin{array}{c}\text { Sum of } \\
\text { Squares }\end{array}$ & Df & Mean Square & F & Sig. \\
\hline 1 Reggresion & 25,354 & 3 & 8,451 & 82,077 & 0,000 \\
Residual & 6,281 & 61 & 0,103 & & \\
Total & 31,635 & 64 & & & \\
\hline Sumber: Data diolah, 2019 & & & &
\end{tabular}

Berdasarkan Tabel 13. dapat dilihat bahwa hasil anova (Uji F), diperoleh nilai antar kelompok pembanding $=3$, nilai dalam kelompok penyebut 64 , pada alfa $=0,05$, maka $\mathrm{F}$ tabelnya adalah $\mathrm{F} 0,05(3,64)=2,75$. Sedangkan $\mathrm{F}$ hitung $=$ 82,077 . nilai $\mathrm{F}$ hitung $\geq \mathrm{F}$ tabel, $82.077 \geq 2,75$, dengan nilai sig $0,000 \leq 0,05$. Maka $\mathrm{H}_{\mathrm{o}}$ ditolak pada taraf nyata $0,05\left(\mathrm{H}_{1}\right.$ diterima). Kesimpulannya, pada kelompok yang diuji memiliki perbedaan yang nyata dan signifikan berarti bahwa pemberdayaan pegawai, dukungan organisasi dan kompensasi secara simultan berpengaruh terhadap komitmen organisasional.

Koefisien determinasi ( $\mathrm{R}$ square) umumnya makin banyak variabel dependen Pemberdayaan Pegawai $\left(\mathrm{X}_{1}\right)$, Dukungan Organisasi $\left(\mathrm{X}_{2}\right)$, dan Kompensasi $\left(\mathrm{X}_{3}\right)$ yang dilibatkan pada suatu persamaan regresi menyebabkan nilai $\mathrm{R}^{2}$ semakin besar dan hampir tidak pernah turun (non decreasing) (Utama, 2016:79). Berdasarkan Tabel 5 hasil analisis regresi linier berganda menghasilkan nilai $\mathrm{R}^{2}$ sebesar 0,801 hal ini berarti 80,1 persen perubahan Komitmen Organisasional (Y) pada Kementerian Pekerjaan Umum dan Perumahan Rakyat Balai Wilayah Sungai Bali-Penida di pengaruhi oleh Pemberdayaan Pegawai $\left(\mathrm{X}_{1}\right)$, Dukungan Organisasi $\left(\mathrm{X}_{2}\right)$,dan Kompensasi $\left(\mathrm{X}_{3}\right)$, sedangkan sisanya 19,9 persen sisanya dipengaruhi oleh variabel lain yang tidak masuk dalam model penelitian ini.

Uji t (t-test) digunakan untuk menguji signifikansi pengaruh variabel independen Pemberdayaan Pegawai $\left(\mathrm{X}_{1}\right)$, Dukungan Organisasi $\left(\mathrm{X}_{2}\right)$, Kompensasi $\left(\mathrm{X}_{3}\right)$ secara parsial terhadap variabel dependen Komitmen Organisasional (Y) pada Pegawai Kontrak di Kementerian PUPR Balai Wilayah Sungai Bali-Penida

Tabel 14.

Hasil Analisis Uji Parsial (Uji t)

\begin{tabular}{lccc}
\hline \multicolumn{1}{c}{ Variabel } & T & Sig. & Hasil hipotesis \\
\hline 1 (Constant) & 0,253 & 0,801 & \\
Pemberdayaan $\left(\mathrm{X}_{1}\right)$ & 2,773 & 0,007 & $\mathrm{H}_{1}$ diterima \\
Dukungan $\left(\mathrm{X}_{2}\right)$ & 2,976 & 0,004 & $\mathrm{H}_{1}$ diterima \\
Kompensasi $\left(\mathrm{X}_{3}\right)$ & 2,319 & 0,024 & $\mathrm{H}_{1}$ diterima \\
\hline
\end{tabular}

Sumber: Data diolah, 2019

Berdasarkan hasil pengujian hipotesis, pengaruh pemberdayaan pegawai terhadap komitmen organisasional dengan hasil (sig.t $0,007 \leq 0,05$ ) serta koefisien regresi sebesar 0,348 menunjukkan bahwa pemberdayaan pegawai berpengaruh positif dan signifikan terhadap komitmen organisasional. Hal ini 
menunjukkan bahwa semakin baik pemberdayaan yang diberikan kepada pegawai kontrak, maka akan meningkatkan komitmen organisasional pegawai kontrak.

Penelitian ini sesuai dengan penelitian yang dilakukan oleh Suardani dan Supartha (2018) mengungkapkan pemberdayaan berpengaruh positif dan signifikan terhadap komitmen organisasional. Adrika dan Ardana, (2017) menyatakan Pemberdayaan Karyawan berpengaruh positif dan signifikan terhadap komitmen organisasional PT. Raditya Dewata Perkasa. Hal ini berarti bahwa semakin baik pemberdayaan maka komitmen organisasional akan semakin kuat. (Wanjiku, 2016) menyatakan bahwa pemberdayaan karyawan berpengaruh positif dan signifikan terhadap komitmen organisasional. Setiawan dan Piartrini (2018) menyatakan bahwa Pemberdayaan karyawan berpengaruh positif dan signifikan terhadap komitmen organisasional pada Villa Ocean Blue. Widayanti dan Sariyathi (2016) mengatakan Pemberdayaan karyawan memiliki pengaruh positif terhadap komitmen organisasi pada CV. Akar Daya Mandiri Cabang Badung.

Berdasarkan hasil pengujian hipotesis, pengaruh dukungan organisasi terhadap komitmen organisasional dengan hasil (sig.t $0,004 \leq 0,05$ ) serta koefisien regresi sebesar 0,375 menunjukkan bahwa dukungan organisasi berpengaruh positif dan signifikan terhadap komitmen organisasional. Hal ini menunjukkan bahwa semakin baik dukungan organisasi yang diberikan kepada pegawai kontrak, maka akan meningkatkan komitmen organisasional pegawai kontrak.

Penelitian ini sesuai dengan penelitian yang dilakukan oleh Fahrizal dan Utama (2017) menyatakan bahwa Persepsi dukungan organisasi berpengaruh positif dan signifikan terhadap komitmen organisasional pada hotel kajane Mua Ubud. Damayanti (2017) mengatakan Dukungan Organisasi berpengaruh signfikan terhadap komitmen organisasi karyawan Universitas Narotama Surabaya. Wijaya dan Yuniawan (2017) menyatakan bahwa Dukungan Organisasi memiliki pengaruh yang positif dan signifikan terhadap variabel Komitmen Organisasi pada PT. Pos Indonesia Processing Center Semarang. Nurhayati (2015) menyatakan bahwa dukungan organisasi berpengaruh positif dan signifikan terhadap komitmen organisasional pada guru taman kanak-kanak di kecamatan sanden. Dewi dan Rahyuda (2015) menyatakan bahwa dukungan organisasi berpengaruh positif dan signifikan terhadap komitmen organisasional.

Berdasarkan hasil pengujian hipotesis, pengaruh kompensasi terhadap komitmen organisasional dengan hasil (sig.t $0,024 \leq 0,05$ ) serta koefisien regresi sebesar 0,245 menunjukkan bahwa kompensasi berpengaruh positif dan signifikan terhadap komitmen organisasional. Hal ini menunjukkan bahwa semakin baik pemberian kompensasi kepada pegawai kontrak, maka akan meningkatkan komitmen organisasional pegawai kontrak.

Penelitian ini sesuai dengan penelitian yang dilakukan oleh Pratama dkk (2016) menyatakan bahwa kompensasi berpengaruh positif terhadap komitmen organisasional. Nurtika dan Sariyathi (2018) menyatakan bahwa Kompensasi Finansial berpengaruh positif terhadap komitmen organisasi pada PT. Asuransi Sinarmas Cabang Denpasar. Novita (2018) menyatakan bahwa kompensasi berpengaruh terhadap komitmen organisasional karyawan koperasi maahasiswa universitas negerti yogyakarta. Saifunurmazah (2018) pada penelitiannya 
mengatakan kompensasi berpengaruh positif terhadap komitmen organisasional pada PT.Bank Mandiri Syariah Tbk, Semarang. Syofiana (2018) menyatakan bahwa kompensasi instrinsik berpengaruh terhadap komitmen organisasional pada Lembaga Penjaminan Mutu Pendidikan Provinsi Sumatera Utara.

Penelitian ini berimplikasi terhadap pengembangan konsep yang berkaitan dengan pemberdayaan pegawai, dukungan organisasi dan kompensasi terhadap komitmen organisasional. Penelitian ini memperkaya bukti empiris hubungan pemberdayaan pegawai, dukungan organisasi dan kompensasi terhadap komitmen organisasional. Hasil penelitian ini jika dikaitkan dengan Social Exchange Teory, maka dikatakan bahwa perusahaan harus memberikan pemberdayaan pegawai, dukungan organisasi, dan pemberian kompensasi harus diperhatikan agar dapat meningkatkan komitmen organisasional pegawai kontrak.

Hasil penelitian ini memberikan sebuah implikasi kepada Kementerian PUPR Balai Wilayah Sungai Bali-Penida mengenai bagaimana pentingnya pemberdayaan pegawai, dukungan organisasi dan kompensasi dapat memengaruhi komitmen organisasional. Penelitian ini juga diharapkan mampu menjadi pertimbangan untuk meningkatkan pemberdayaan pegawai, dukungan organisasi, dan kompensasi agar dapat meningkatkan komitmen organisasional pegawai kontrak.

\section{SIMPULAN}

Simpulan dari penelitian ini : 1). Pemberdayaan Pegawai berpengaruh positif dan siginifikan terhadap komitmen organisasional pada Kementerian PUPR Balai Wilayah Sungai Bali-Penida. Hal ini menunjukkan jika pegawai kontrak semakin diberdayakan maka semakin tinggi komitmen organisasional yang dimiliki oleh masing-masing individu pegawai kontrak ; 2). Dukungan Organisasi berpengaruh positif dan signifikan terhadap komitmen organisasional pada Kementerian PUPR Balai Wilayah Sungai Bali-Penida. Ini menunjukkan bahwa apabila pimpinan memberikan dukungan organisasi kepada pegawai kontrak maka kenyamanan saat bekerja meningkat serta komitmen organisasional akan meningkat;3). Kompensasi berpengaruh positif dan signifikan terhadap komitmen organisasional. Hal ini menunjukkan jika pemberian kompensasi kepada pegawai kontrak secara adil tentu akan meningkatkan komitmen organisasional karena merasa prestasinya dihargai oleh pimpinan.

Saran dalam penelitian ini : 1). Pihak manajemen Kementerian PUPR Balai Wilayah Sungai Bali-Penida memperhatikan faktor-faktor yang mempengeruhi komitmen organisasional pegawai kontrak dengan lebih baik sehingga jika pegawai kontrak jika menerima tawaran dari perusahaan lain mereka tidak terpengaruh karena sudah mempunyai komitmen pada organisasi tempatnya bekerja; 2). Jika pimpinan sudah memberdayakan dengan cara memberikan kebebasan pegawai kontrak dalam memutuskan bagaimana cara menyelesaikan suatu pekerjaan, tentu pegawai kontrak akan merasa lebih diberdayakan oleh perusahaan sehingga komitmen organisasional pegawai kontrak meningkat; 3). Pimpinan perusahaan harus memberikan dukungan kepada pegawai kontrak didalam menyelesaikan suatu pekerjaan yang dianggap berat dan mau 
mendengarkan keluh kesah bawahan pada saat terdapat masalah mengenai pekerjaannya; 4). Perusahaan memberikan kompensasi kepada pegawai kontrak harus memperhatikan bagaimana output pegawai kontrak, sehingga pegawai kontrak yang mempunyai keterampilan akan merasa adil karena kompensasi yang diberikan sesuai dengan tingkat keterampilan yang dimiliki.

\section{REFERENSI}

Ardana, I. K., Mujiati, N.W., Utama, I. W. M. (2012). Manajemen Sumber Daya Manusia. Yogyakarta: Pt. Graha Ilmu.

Adrika, N. P., \& Ardana, I. K. (2017). Pengaruh Pemberdayaan Karyawan Dan Kepuasan Kerja Terhadap Komitmen Organisasional Pada Pt. Raditya Dewata Perkasa. E-Jurnal Manajemen Unud. 6(11), 6141-6166.

Adekola, B. (2012). The Impact of Organizational Commitment on Job Satisfaction: A Study of Employees at Nigerian Universities. International Journal of Human Resource Studies. 2(2), 1-17.

Adhika, I. N. R ., \& Riana, I. G. (2016). Pengaruh Dukungan Organisasional dan Kepuasan Kerja terhadap Komitmen Karyawan ( Studi pada Koperasi Simpan Pinjam di Denpasar Utara ). E-Jurnal Manajemen Unud, 5(4), 857876.

Arta, I. G. N. W., \& Surya, I. B. K. (2017). Pengaruh Kompensasi Terhadap Komitmen Organisasional Dan Turnover Intention Pada Agent Pru Megas. E-Jurnal Manajemen Unud. 6(8), 4156-4184.

Blau, P. M. (1964). Exchange and Power in Social Life. Chicago: Jhon Willey Son. INC.

Chiang, C., \& Hsieh, T. (2012). The impacts of perceived organizational support and psychological empowerment on job performance: The mediating effects of organizational citizenship behavior. International Journal of Hospitality Management. 31(1), 180-190.

Darmawan. (2013). Metode Penelitian Kuantitatif. Bandung. Remaja Rosdakarya.

Damayanti, E. (2017). Pengaruh Role Stressor Dan Persepsi Dukungan Organisasi Terhadap Kepuasan Kerja Dan Komitmen Organisasi Di Universitas Narotama Surabaya. E-Jurnal Spirit Pro Patria. 3(1), 96-109.

Dewi, M. D., \& Rahyuda, A. G. (2015). Peran Pemediasian Komitmen Organisasi Pada Pengaruh Perceived Organizational Support Terhadap Intention To Leave. E-Jurnal Manajemen Unud. 4(10), 2928-2954. 
Elnaga, A. A., \& Imran, A. (2014). The Impact of Employee Empowerment on Job Satisfaction Theoretical Study. American Journal of Research Communication. 2(1), 13-26.

Eisenberger, R., Malone, G.P., \& Presson, W. D. (2017). Optimizing Perceived Organizational Support To Enhance Employee Engagement. Shrm-Siop Science Of Hr Series.

Febriwanti, Zulfadil, \& Samsir. (2017). Pengaruh Kepemimpinan , Fokus pada Konsumen , Pemberdayaan Karyawan , dan Manajemen Proses terhadap Kepuasan Kerja Karyawan PT Telkomsel Area Pekanbaru. Jurnal SOROT. 12(1), 55-70.

Fahrizal, \& Utama, I. W. M. (2017). Pengaruh Persepsi Dukungan Organisasi Terhadap Komitmen Organisasional Dan Turnover Intention Karyawan Hotel Kajane Mua Ubud. E-Jurnal Manajemen Unud. 6(10), 5405-5431.

Fung, N. S., Ahmad, A., \& Omar, Z. (2012). Work-Family Enrichment: It 's Mediating Role in the Relationships between Dispositional Factors and Job Satisfaction. International Journal of Academic Research in Business and Social Sciences. 2(11), 73-88.

Ghosh, A. K. (2013). Employee Empowerment: A Strategic Tool to obtain Sustainable Competitive Advantage. International Journal of Management. 30(3), 95-107.

Hasibuan, Malayu, Sp. (2014). Manajemen Sumber Daya Manusia. Edisi Revisi, Penerbit: Bumi Aksara, Jakarta.

Hutagaol, I. M. (2014). Employee Empowerment On Organizational Commitment In Bank Indonesia Representative In North Sulawesi. Jurnal EMBA. 2(3), 921-930.

Haq. M. A. U, Jindong.Y, Hussain.N, \& Anjum. Z. (2014). Factors Affecting Organizational Commitment Among Bank Officers In Pakistan. Journal of Business and Management. 16(4), 18-24.

Karambut, C. A., \& Noormijati, E. A. T. (2012). Analisis Pengaruh Kecerdasan Emosional , Stres Kerja dan Kepuasan Kerja terhadap Komitmen Organisasional ( Studi pada Perawat Unit Rawat Inap RS Panti Waluya Malang ). Jurnal Aplikasi Manajemen. 10(3), 655-668.

Kazlauskaite, R., Buciuniene, I., \& Turauskas, L. (2014). Organisational and psychological empowerment in the HRM-performance linkage. Emerald Insight. 34(2), 138-158.

Kuo, T. H., Ho, L.A., Lin, C., \& Lai, K. (2010). Employee empowerment in a 
technology advanced work environment. Indutrial Management \& Data System, 110(1), 24-42.

Labri, A. (2014). Effect Of Compensation Management On Employee Performance At The St . Michael' S Catholic Hospital, Pramso. Thesis. Master of Business Administration Kwame Nkrumah University of Science and Technology.

Meyer, J. P., \& Allen, N. J. (1991). A Three-Component Conceptualization Of Organizational Commitment. Human Resource Management Review. 1(1), 61-89.

Nurtika, H., \& Sariyathi, N. K. (2018). Pengaruh Kompensasi Finansial Dan Kepuasan Kerja Terhadap Komitmen Organisasi Pada Pt. Asuransi Sinarmas Cabang Denpasar. E-Jurnal Manajemen Unud. 7(5), 2764-2792.

Nurhayati, A. E. (2015). Pengaruh Kepuasan Kerja, Motivasi, Dan Persepsi Atas Dukungan Organisasional Terhadap Komitmen Organisasi Guru Taman Kanak- Kanak Di Kecamatan Sanden, Kabupaten Bantul, Yogyakarta. Jurnal Manajemen. 5(1), 11-17.

Novita, D. (2018). Pengaruh Budaya Organisasi Dan Kompensasi Terhadap Komitmen Karyawan Koperasi Mahasiswa Universitas Negeri Yogyakarta. Jurnal Ekobis Dewantara. 1(1), 159-166.

Pratama, E. ., Musadieq, M. A., \& Mayowan, Y. (2016). Pengaruh Kompensasi Dan Kepusan Kerja Terhadap Komitmen Organisasional (Studi Pada Karyawan Ksp Sumber Dana Mandiri Gresik). Jurnal Administrasi Bisnis (JAB). 34(1), 1-9.

Robbins, S. P. (2010). Essensials Of Organizational Behavior. Printice Hall International, Inc, New Jersey.

Suardani, N. M. D., \& Supartha, I. W. G.(2018). Pengaruh Pemberdayaan, Kepemimpinan Transformasional Dan Keadilan Organisasional Terhadap Komitmen Organisasional Karyawan. E-Jurnal Manajemen Unud.7(3), 1426-1451.

Sugiyono. (2017). Metode Penelitian Kuantitatif, Kualitatif , Kombinasi dan $R \& D$. Bandung: Cv. Alfabet.

Serim, H., Demirbag, O., \& Yozgat, U. (2014). The effects of employees perceptions of competency models on employability outcomes and organizational citizenship behavior and the moderating role of social exchange in this effect. Procedia Journal of Social And Behavioral Sciences. 150(1), 1101-1110. 
Sjahruddin, H. (2013). Organizational Justice, Organizational Commitment and Trust in Manager as predictor of Organizational Citizenship Behavior. Interdisciplinary Journal Of Contemporary Research In Business. 4(12), $133-141$.

Saifunurmazah, D. (2018). Pengaruh Gaya Kepemimpinan, Kompensasi Dan Motivasi Terhadap Komitmen Organisasional (Studi pada PT Bank Mandiri Syariah Tbk Semarang). Jurnal Magisma. 6(2), 13-19.

Syofiana, Y. (2018). Analisis Pelatihan , Kompensasi Intrinsik dan Lingkungan Kerja Non Fisik Terhadap Komitmen Organisasional ( Studi pada Lembaga Penjaminan Mutu Pendidikan Provinsi Sumatera Utara ). Jurnal TALENTA. 1(1), 214-225.

Setiawan, I. P. I., \& Piartrini, P. S. (2018). Pengaruh Pemberdayaan Karyawan Dan Tres Kerja Terhadap Komitmen Organisasional Karyawan Departemen Housekeeping Pada Villa Ocean Blue. E-Jurnal Manajemen Unud. 7(1), 164-191.

Sedarmayanti. (2009). Sumber Daya Manusia Dan Produktivitas Kerja. Bandung: $\mathrm{Cv}$ Mandar Maju.

Turgut, H., Tokmak, I., \& Gucel, C. (2012). The Effect Of Employees Organizational Justice Perceptions On Their Organizational Commitment: A University Sample. International Journal Of Business And Management Studies. 4(2), 21-30.

Utama, M. S. (2016). Aplikasi Analisis Kuantitatif. Fakultas Ekonomi Dan Bisnis Universitas Udayana Denpasar : Cv.Sastra Utama.

Widiarti, N. L. P. D., \& Dewi, A. A. S. K. (2016). Pengaruh Iklim Organisasi Dan Kepuasan Kerja Terhadap Komitmen Organisasional Pada Dinas Pendapatan Provinsi Bali. E-Jurnal Manajemen Unud.5(10), 6345-6372.

Wanjiku, M. M . (2016). Influence Of Employee Empowerment On Organizational Commitment In Kenya Civil Service. Thesis. Kenyatta University Of Agriculture And Technology.

Widodo, S. E. (2015). Manajemen Pengembangan Sumber Daya Manusia. Yogyakarta. Pustaka Pelajar.

Widayanti, K. S., \& Sariyathi, N. K. (2016). Pengaruh Kepuasan Kerja, Pemberdayaan Karyawan, Dan Stres Kerja Terhadap Komitmen Organisasi 
Kadek Desniari, Pengaruh Pemberdayaan Pegawai...

Pada Cv. Akar Daya Mandiri. E-Jurnal Manajemen Unud. 5(11), 70227049.

Wijaya, N. A., \& Yuniawan, A. (2017). Analisis Pengaruh Budaya Organisasi Dan Dukungan Organisasi Terhadap Organizational Citizenship Behavior Dengan Komitmen Organisasi Sebagai Variabel Intervening. Diponegoro Journal Of Managemen. 6(4), 1-13. 